OKU Journal of Natural and Applied Sciences
Volume 4, Issue 1,91-95, 2021

\title{
Organik Malç Uygulamalarının Toprağın Bazı Fiziksel Özellikleri Üzerine Etkileri
}

\section{Zekeriya KARA ${ }^{1 *}$, Sertan SESVEREN², Engin GÖNEN ${ }^{3}$, Asiye KÖYLÜ ${ }^{4}$}

${ }^{1}$ Kahramanmaraş Sütçü İmam Üniversitesi Üniversite-Sanayi Kamu İşbirliği Geliştirme, Uygulama ve Araştırma Merkezi Müdürlüğü (ÜSKİM)

Toprak Bilimi ve Bitki Besleme Bölümü

${ }^{2,4}$ Kahramanmaraş Sütçü İmam Üniversitesi, Ziraat Fakültesi, Biyosistem Mühendisliği Bölümü, Kahramanmaraş

${ }^{3}$ Alata Bahçe Kültürleri Araştırma Enstitüsü Müdürlüğü, Toprak ve Su Kaynakları Bölümü, Mersin

${ }^{1}$ https://orcid.org/0000-0001-7855-4968

${ }^{2}$ https://orcid.org/0000-0002-5163-7066

${ }^{3}$ https://orcid.org/0000-0002-0471-9376

${ }^{4}$ https://orcid.org/0000-0001-8626-4215

*Sorumlu yazar: zkara@ksu.edu.tr

\section{Araştırma Makalesi}

\section{Makale Tarihçesi:}

Geliş tarihi: 12 Ekim 2020

Kabul tarihi: 24 Aralık 2020

Online Yayınlanma: 2 Mart 2021

\section{Anahtar Kelimeler:}

Buğday samanı

Toprak su içeiği

Tarla kapasitesi

Yarı-kurak iklim koşulları

\begin{abstract}
ÖZET
Bu çalışma, Türkiye'nin Doğu Akdeniz Bölgesinde yarı-kurak iklim koşullarında buğday yetiştirilen arazilerde organik malç uygulamalarından birisi olan buğday samanı uygulamasının toprak özellikleri üzerine etkisini belirlemek amaciyla yapılmıştır. Çalışmada toprak yüzeyine farklı oranlarda $(0,300 \mathrm{~kg} / \mathrm{da}, 600 \mathrm{~kg} / \mathrm{da}$ ve $900 \mathrm{~kg} / \mathrm{da}$ ) buğday samanı uygulanmıştır. Deneme, arazi koşullarında, tesadüf blokları deneme desenine göre 3 tekerrürlü olarak kurulmuştur. Buğday hasat sonrası her parselden $0-15 \mathrm{~cm}$ derinlikten toprak örnekleri alınmıştır. Sonuçta, organik malç uygulamalarından buğday samanının uygulamalara bağlı olarak toprağın organik madde miktarını artırdığı tespit edilmiştir. Ayrıca buğday samanının toprakların likit limit, plastik limit, yarayışlı su içeriği ve tarla kapasitesini de artırmıştır. Uygulama dozuna bağlı olarak toprağın likit limit, plastik limit, yarayışlı su içeriği ve tarla kapasite artışı organik madde ile ilişskilendirilmiştir. Yapılan istatistiksel analiz sonucuna göre, organik madde, likit limit, plastik limit, yarayışlı su içeriği ve tarla kapasitesi üzerine $(\mathrm{P}<0,05)$ önemli farklılıklar bulunmuştur. Kahramanmaraş koşullarında $600 \mathrm{~kg} / \mathrm{da}$ ve $900 \mathrm{~kg} / \mathrm{da}$ buğday samanının uygulamalarının topraklarda organik maddenin artırılması, bitkiye elverişli su kapasitesini artırdığı, yüzey akışını azalttı̆̆ı, porozite özelliklerini iyileştirerek kök bölgesinde su ve hava tutma dengesi sağlayabileceği, dolayısıyla bitkisel üretimde verim ve kaliteyi artıracağı sonucuna varılmıştır.
\end{abstract}

Effects of Organic Mulch Applications on Some Physical Properties of Soil

\section{Research Article}

\section{Article History:}

Received: 12 October 2020

Accepted: 24 December 2020

Published online: 2 March 2021

\section{Keywords:}

Wheat straw

Soil water content

Field capacity

Semi arid conditions

\begin{abstract}
This study was carried out in order to determine the effect of organic mulch on the soil properties of wheat straw in wheat fields. Turkey's semi-arid climatic conditions in the Eastern Mediterranean Region. In the study, wheat straw in different proportions $(0,300 \mathrm{~kg} / \mathrm{da}, 600 \mathrm{~kg} / \mathrm{da}$ and $900 \mathrm{~kg} / \mathrm{da})$ was applied to the soil surface. The trial was set up with 3 replications according to the randomized blocks trial pattern under field conditions. After the wheat harvest, soil samples were taken from each parcel at a depth of $0-15 \mathrm{~cm}$ and analyzed in laboratory. As a result, it has been determined that wheat straw applications, increases the organic matter of the soil depending on the applications. In addition, wheat straw increased the liquid limit, plastic limit, available water content and field capacity of the soils. Depending on the application dose, liquid limit of the soil, plastic limit, available water content and field capacity increase were associated with organic matter. According to the results of statistical analysis, significant differences were found on organic matter, liquid limit, plastic limit, available water content and field
\end{abstract}


capacity $(\mathrm{P}<0,05)$. It has been concluded that the application of $600 \mathrm{~kg} / \mathrm{da}$ and 900 $\mathrm{kg} / \mathrm{da}$ wheat straw in Kahramanmaraş conditions will increase the organic matter in the soil, increase the water capacity suitable for the plant, decrease the surface flow, improve the porosity properties and provide water and air retention balance in the root zone, thus increasing the yield and quality in crop production.

To Cite: Kara Z., Sesveren S., Gönen E., Köylü A. Effects of Organic Mulch Applications on Some Physical Properties of Soil. Osmaniye Korkut Ata Üniversitesi Fen Bilimleri Enstitüsü Dergisi 2021; 4(1): 91-95.

\section{Introduction}

Increasing global crop production will be one of the greatest challenges facing humanity in the coming decades. The aim of agriculture is to help the generations to continue their lives in a healthy way by providing the food need for human survival. Therefore, the soil, climate and plants should be protected. For this reason, it has been forced to take more products from the soil per unit area and to work to eliminate the factors that cause this restriction in areas where production is restricted for one or more reasons. These restricts; Restrictions include areas with poor chemical and physical properties, climate in arid-semi-arid regions, especially rainfall and production of the precipitation regime.

Today, 6,1 billion ha of the world's lands are composed of arid and semi-arid areas. Drought is the most important environmental factor limiting plant growth and reducing crop production in the world's agricultural areas where the Mediterranean climate prevails. Mediterranean region at the beginning of the areas most affected by global warming will come. As is known, the most important factor limiting plant growth in arid and semi-arid climates is the lack of available water in the root zone $[1,2]$. As a result of low rainfall and excessive evaporation in these areas, water shortage is observed for plant development, and water shortage is one of the most important problems of crop production.

Excessive evaporation requires moisture control in the soil. By controlling the moisture in the soil, it makes it possible to keep the moisture in the soil for a long time and to prevent the salinization that occurs on the soil surface by evaporation.

Preserving the soil moisture content can be achieved by covering the soil surface with some cover materials. Various organic and inorganic mulches can be used for this purpose. Mulching protects the soil against the erosive forces of precipitation by reducing the hydrodynamic forces of the aggregates falling on the soil surface and by absorbing the kinetic energy of the raindrops by reducing the hydrodynamic forces of the raindrops falling on the surface of the soil, and also decreases the soil loss by increasing the amount of surface runoff and its velocity by increasing the infiltration [3].

The effectiveness of mulch materials applied to soils can vary significantly depending on factors such as climate and soil properties, mulch type, amount, application method and time. It has been reported that as the amount of covering the soil surface with organic mulch increases, soil losses decrease Organic mulch application on soil surfaces significantly reduces soil losses that may occur due to precipitation and winds. It has been stated by many researchers that organic mulching of soils increases the organic matter content and stability of the topsoil $[2,4,5]$

This study aimed to determine the effects of organic mulching (wheat straw) application on some physical properties of soils after harvest under arid-semi-arid climatic conditions in Kahramanmaraş province.

\section{Material and Method}

\subsection{Material}

The field experiment was conducted at the east mediterranean transitional zone agricultural research of institute, in Kahramanmaraş, Turkey. Some physico-chemical analysis results of the experimental soils are given in Table 1.

Table 1. Some physico-chemical analysis results of the experimental soils

\begin{tabular}{cccccc|ccccc}
\hline $\mathrm{pH}$ & Lime & OM & Clay & Sand & Silt & $\mathrm{P}$ & $\mathrm{K}$ & $\mathrm{Ca}$ & $\mathrm{Mg}$ & $\mathrm{Na}$ \\
\hline 7,76 & 35,57 & 2,40 & 26,13 & 28,29 & 45,58 & 5 & 189,6 & 6500 & 972 & 49,6 \\
\hline
\end{tabular}


Wheat straw was used as organic mulch on the trial soil. The experiment was carried out with 3 replications according to the randomized blocks design by making factorial arrangements. After planting wheat, 4 different doses (Control, 300 $\mathrm{kg} / \mathrm{da}, \quad 600 \mathrm{~kg} / \mathrm{da}$ and $900 \mathrm{~kg} / \mathrm{da}$ ) were homogeneously distributed by hand in the study area. The trial started in mid-November and ended towards the end of June. After the trial was completed, soil samples were taken and appropriate physical analyzes were made.

\subsection{Method}

The plastic limit value of the soils taken from the study area was determined according to the Sower, [6] method, and the liquid limit values of the soils were determined using the casagranda tool [7]. The field capacity and permanent wilting point of the soils are expressed as the amount of water held under pressures of 33 and $1500 \mathrm{kPa}$, respectively, in the pressure table device after the samples are saturated with water [8]. The organic matter content of soils was determined according to the method determined by Nelson and Sommers [9].

Analysis of variance was performed to evaluate the statistical effect of treatments on some soil properties SPSS software. Treatment means were compared using LSD test [10].

\section{Results and Discussion}

The change of the wheat straw levels applied in the study on the soil organic matter amounts are given in Figure 1.

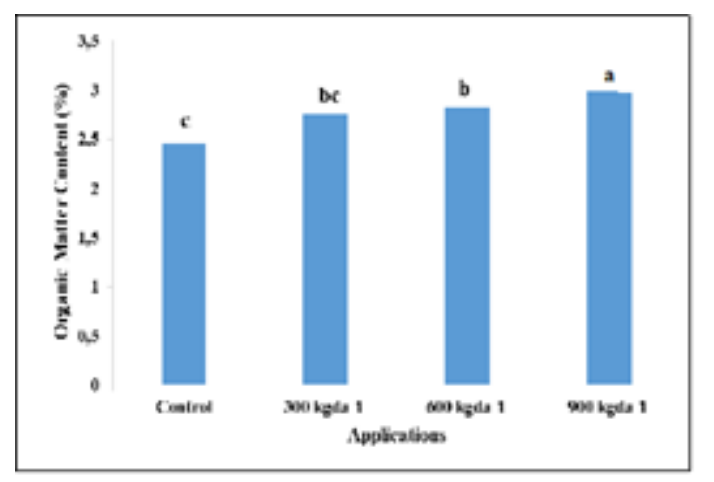

Figure 1. Change of organic matter contents depending on the application

The highest amount of organic matter is seen at $900 \mathrm{~kg} / \mathrm{da}$ straw applied points $2,99 \%, 2,82 \%$ in $600 \mathrm{~kg} / \mathrm{da}$ applications and the lowest organic matter content was determined in control $(2,45 \%)$. According to the results of the Anova test, a statistically significant difference was found between the change in organic matter amounts and the application doses $(\mathrm{P}<0,05$; Figure 1$)$.

The liquid limit values of the soils subject to the experiment are given in Figure 2.

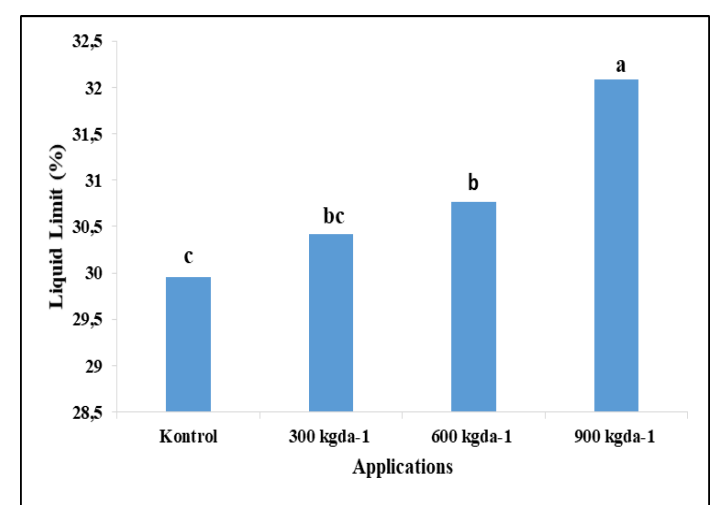

Figure 2. Application-dependent change of liquid limit

The liquid limit values of the soils increased depending on the increasing dose amount. While the lowest liquid limit value was observed in the control soil $(29,02 \%)$ without any application, the highest liquid limit value was found in the parcel where $900 \mathrm{~kg} / \mathrm{da}$ of straw was applied per decare $(32,48 \%)$. Application doses were found to be statistically significant on liquid limit amounts ( $\mathrm{P}$ $<0,05)$. The increase in liquid limit values due to the application has been associated with organic matter. Smith et al. [11] stated that there are positive relationships between organic matter and liquid limit. It has been stated by many researchers that organic matter has direct or indirect positive relationships on soil quality $[12,13,14]$.

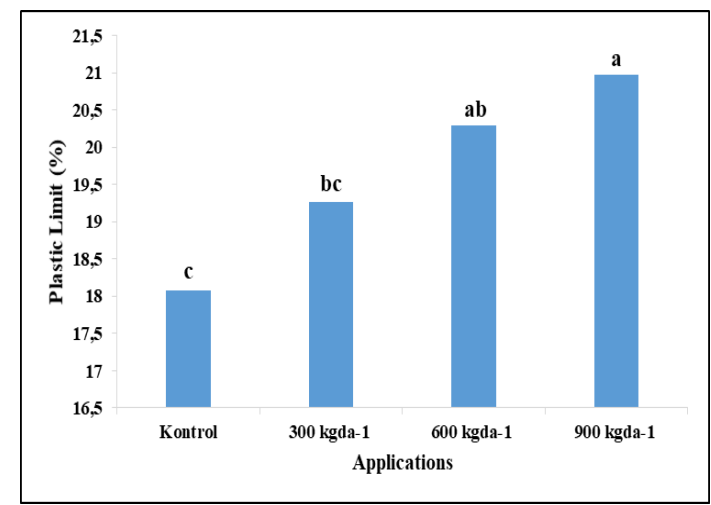

Figure 3. Application-dependent variation of the plastic limit

According to the Figure 3 given, in parallel with the application dose of wheat straw from agricultural waste, the plastic limit values of the soils have increased. While the highest plastic limit value was $21,18 \%$ in the parcel where 900 $\mathrm{kg}$ of wheat straw was applied per decare, the 
lowest plastic limit value was observed in the control parcel $(16,67 \%)$. According to the ANOVA test result, the applications were found to be statistically significant above the plastic limit $(\mathrm{P}<0,05)$. The increase in plastic limit values due to the application has been associated with organic matter. Gülser and Candemir [15] stated that due to the increase in organic matter, plastic limit also increased from Atterberg limits.

The variation of the field capacity and available water content of the soils subject to study is given in Figure 4 and Figure 5, respectively.

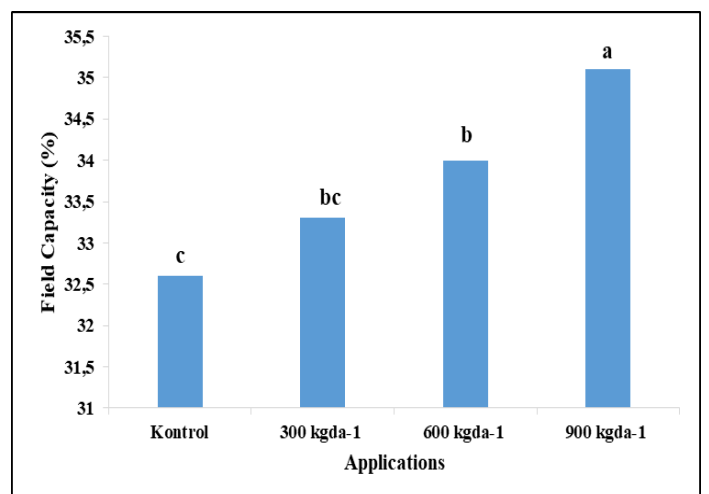

Figure 4. Variation of field capacity depending on the application

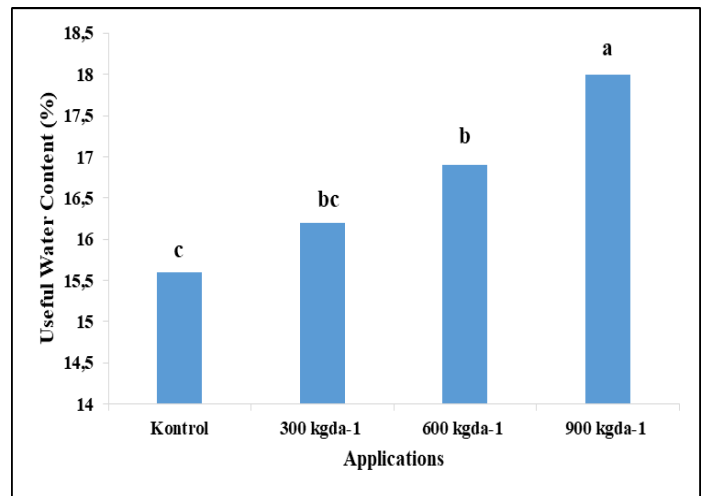

Figure 5. Application-dependent variation of useful water content

While the highest field capacity was observed in the parcels with $900 \mathrm{kgs}$ per decare $(35,1 \%)$, the lowest value was detected at the control point $(32,6 \%)$. When we look at the available water content of the experimental plots, the lowest control point $(15,6 \%)$ and the highest point where $900 \mathrm{~kg}$ of wheat straw was applied per decare $(18 \%)$ was obtained. The increase in field capacity and available water content was associated with organic matter. According to the ANOVA test results, the field capacity and available water content were found to be statistically significant $(\mathrm{P}<0,05)$. In the study conducted by Montenegro et al. [16], it was stated that vegetal waste practices significantly increased the amount of moisture retained in the soil. Another researcher reported that straw mulchers support water storage of soils [17]. The results we obtained in the field of study support previous studies. As the amount of chaff in the trial plots increased, the amount of organic matter changed compared to the control. With the increase in organic matter, the variables of liquid limit, plastic limit and field capacity, which is a character of water holding capacity, increased in direct proportion.

\section{Conclusion}

In this study, the changes caused by wheat straw from agricultural wastes on the moisture content of soils were investigated.

It has been concluded that the changes occurring in the organic matter amounts of the soils and the applications are effective. Due to the increase in organic matter, the liquid limit, plastic limit, field capacity and available water amount of the soils increased. According to the results of statistical analysis

Considering its importance in dry agriculture and soil moisture, increasing the organic matter in poor soils increases the water capacity suitable for the plant, decreases the surface flow, increases the water and air holding ability of the soil by improving its porosity properties, thus increasing the yield and quality in crop production. In order to prevent yield decreases due to low rainfall conditions in first crop wheat cultivation under Kahramanmaraş conditions, application of $600 \mathrm{~kg}$ and $900 \mathrm{~kg}$ of wheat straw per decare can provide a good air-water balance in the root zone, especially as a result of organic matter increase and improvement of aggregate structures. In addition, it can be predicted that mulch will provide positive results in above-ground water content retention.

In the light of the findings obtained from this study, if long-term aggregation is desired in the territory of the region, it can be recommended to use it with organic matter regulators in addition to vegetable mulch. The rate of change in our study was generally lower than the findings in organic mulch applications in the literature. For long-term improvements, new studies can be carried out under quantity adjustment, application times, soil types, climatic characteristics and different agricultural conditions. It may be suggested that different dose combinations be developed. The results of the applications will reflect positively on the economic indicators of agricultural 
production. In addition, recommendations at the farmer level should be developed based on the results of the trials to be carried out in parcel conditions.

\section{Statement of Conflict of Interest}

Authors have declared no conflict of interest.

\section{Author's Contributions}

The contribution of the authors is equal.

\section{References}

[1] Falkenmark M., Rockström J. Curbing rural exodus from tropical drylands, Ambio. Stockholm 1993; 22(7): 427-437.

[2] Lal R., Stewart BA. Managing soils for enhancing and sustaining agricultural production, Soil Management: Experimental Basis for Sustainability and Environmental Quality. CRC Lewis Publishers, Boca Raton 1995; FL, pp. 1-9.

[3] Osunbitan JA., Adekalu KO. Percent mulch cover and rainfall duration effect on soil loss and runoff from three southwestern Nigerian soils, Ife Journal of Technology 2000; 9: 125-130.

[4] Havlin JL., Kissel DE., Maddus LD., Claassen MM., Long JH. Crop rotation and tillage effects on soil organic carbon and nitrogen, Soil Science Society of America Journal, 1990; 54: 448-452.

[5] Mulumba LN., Lal R. Mulching effects on selected soil physical properties, Soil Tillage Res 2008; 98: 106-111.

[6] Sowers GF. Consistency Methods of Soil Analysis, American Society of Agronomy, Madison, Wisconsin U.S.A agricultural 1965; 137: 226-230.

[7] Head KH. Manual of Soil Laboratory Testing 1984; 1, USA.

[8] Klute A. Methods of soil analysis. Part 1. Physical and Mineralogical Methods, 2nd ed. Agron. Monogr 1986; 635-653.

[9] Nelson DW., Sommers LE. Total carbon, organic carbon, and organic matter. P: 9611011. In DL. Sparks (ed) Method of
Soil Analysis: Chemical Methods. Part 3. SSSA, Madison, WI; 1996.

[10] Field A. Discovering statistics using IBM SPSS statistics. Sage, 2013

[11] Smith CW., Hadas JD., Koyumdjisky H. Shrinkage and atterberg limits in relation to other properties of principal soil types in Israel, Geoderma 1985; 35(1): 47-65.

[12] Yakupoğlu, T., Özdemir, N. Erozyona uğramış topraklarda organik atık uygulamalarının bazı mekaniksel özelliklere etkisi. OMÜ Ziraat Fak. Dergisi 2006; 21(2):173-178.

[13] Bhushan L., Sharma PK. Long-term effects of lantana (Lantana spp. L.) residue additions on soil physical properties under rice-wheat cropping. I. Soil consistency, surface cracking and clod formation, Soil and Tillage Research 2002; 65(2): 157-167.

[14] Kara Z., Yakupoğlu T., Sesveren S., Solak S., Saltalı K. Applied to Agriculture Soil Gyttja: Effect on the atterberg limits and some physical parameters. Proceedings Book: 1th International GAP Agriculture and Livestock Congress 2018; 441-445.

[15] Gülser C., Candemir F. Changes in atterberg limits with different organic waste application, In: Proceedings of International Soil Congress (ISC) on Natural Resource Management for Sustainable Development, 2004; pp: 8-15

[16] Montenegro AAA., Abrantes JRCB., De Lima JLMP., Singh VP., Santos TEM. Impact of mulching on soil and water dynamics under intermittent simulated rainfall, Catena 2013b; 109: 139-149.

[17] Jiménez MN., Pinto JR., Ripoll MA., Sánchez-Miranda A., Navarroc FB. Impact of straw and rock-fragment mulches on soil moisture and early growth of holm oaks in a semiarid area, Catena 2017; 152: 198-206. 